\title{
Brain-Derived Neurotrophic Factor Treatment Increases the Skeletal Muscle Glucose Transporter 4 Protein Expression in Mice
}

\author{
M. SUWA ${ }^{1}$, K.-I. YAMAMOTO ${ }^{2}$, H. NAKANO ${ }^{3}$, H. SASAKI ${ }^{4}$, Z. RADAK ${ }^{5}$, S. KUMAGAI ${ }^{2,4}$ \\ ${ }^{1}$ Faculty of Life Design, Tohoku Institute of Technology, Taihaku-ku, Sendai, Miyagi, Japan, \\ ${ }^{2}$ Graduate School of Human-Environment Studies, Kyushu University, Kasuga, Fukuoka, Japan, \\ ${ }^{3}$ Department of Human Development, Nakamura Gakuen University, Jonan-ku, Fukuoka, Japan, \\ ${ }^{4}$ Institute of Health Science, Kyushu University, Kasuga, Fukuoka, Japan, ${ }^{5}$ Research Institute of \\ Sport Science, Faculty of Physical Education and Sport Science, Semmelweis University, Budapest, \\ Hungary
}

Received March 4, 2009

Accepted August 17, 2009

On-line November 20, 2009

\section{Summary}

The purpose of the present study was to investigate whether peripheral brain-derived neurotrophic factor (BDNF) treatment induced metabolic adaptations in mouse skeletal muscle. BDNF (20 mg/kg/day) was injected subcutaneously for successive 14 days. BDNF treatment significantly reduced the total food intake and inhibited the weight gain in comparison to the control group. The glucose transporter 4 (GLUT4) protein expression in the gastrocnemius muscle was significantly increased by BDNF treatment in comparison to the control and pair-fed groups. Neither the oxidative nor the glycolytic enzyme activities in the gastrocnemius muscle changed after the BDNF treatment. These results suggest that the peripheral BDNF treatment promotes the skeletal muscle GLUT4 protein expression as well as hypophagia.

\section{Key words}

BDNF • GLUT4 • Hypophagia • Skeletal muscle

\section{Corresponding author}

M. Suwa, Faculty of Life Design, Tohoku Institute of Technology, 6 Futatsusawa, Taihaku-ku, Sendai, Miyagi, 982-8588, Japan. Fax: +81-22-304-5591. E-mail: suwa-m@tohtech.ac.jp

Brain-derived neurotrophic factor (BDNF) is a part of the neurotrophin family and is produced in the nervous system and periphery. The BDNF controls the food consumption ( $\mathrm{Xu}$ et al. 2003), lipid and glucose metabolism (Nakagawa et al. 2000, Tsuchida et al. 2002), and insulin resistance (Kuroda et al. 2003). Recent human studies have shown that circulating BDNF is associated with eating disorders (Nakazato et al. 2003, Monteleone et al. 2004), obesity (Monteleone et al. 2004, Suwa et al. 2006), glucose and lipid metabolism (Suwa et al. 2006, Levinger et al. 2008), type II diabetes mellitus (Suwa et al. 2006) and metabolic syndrome (Chaldakov et al. 2003, 2004). Based on these metabolic contributions, BDNF is considered to be a "metabotrophins" (Chaldakov et al. 2007).

Skeletal muscle metabolic characteristics such as glucose transporter 4 (GLUT4) expression and mitochondrial oxidative capacity are associated with skeletal muscle insulin-stimulated glucose uptake, whole body insulin sensitivity and prevalence of type II diabetes mellitus (He et al. 2001, Bruce et al. 2003, Doehner et al. 2010). Chronic BDNF treatment to diabetic mice significantly improves the glucose uptake in skeletal muscle (Yamanaka et al. 2007). Based on these results, the BDNF is hypothesized to regulate the skeletal muscle metabolism. This study examined whether chronic BDNF treatment to mice affects skeletal muscle metabolic characteristics such as GLUT4 protein expression and glycolytic and oxidative enzyme activities.

Sixty-nine- to 72-day old female ICR mice were

PHYSIOLOGICAL RESEARCH • ISSN 0862-8408 (print) • ISSN 1802-9973 (online)

(c) 2010 Institute of Physiology v.v.i., Academy of Sciences of the Czech Republic, Prague, Czech Republic

Fax+420 241062 164, e-mail: physres@biomed.cas.cz, www.biomed.cas.cz/physiolres 
used for the current study. All mice were fed a standard rodent chow (CE-2, CLEA Japan, Inc., Tokyo, Japan). All experimental procedures were approved by the Nakamura Gakuen University Animal Experiment Committee.

Because BDNF treatment reduces food intake (Nakagawa et al. 2003), the effects of BDNF treatment was studied in comparison with both ad libitum-fed control and pair-fed mice. The mice were divided into an ad libitum-fed $(\mathrm{AL}, \mathrm{n}=8)$, a pair-fed $(\mathrm{PF}, \mathrm{n}=8)$, or a BDNF-treated (BDNF, $n=8$ ) group. The mice of the BDNF group were subcutaneously administered daily with $20 \mathrm{mg} / \mathrm{kg}$ body mass BDNF (Dainippon Sumitomo Pharma, Osaka, Japan) in saline for 14 successive days. This dose of BDNF has been shown to enhance the skeletal muscle glucose uptake (Yamanaka et al. 2007). In the AL and PF groups, a comparable volume of saline was administered subcutaneously.

About $24 \mathrm{~h}$ after the last administration, the mice were fasted for $4 \mathrm{~h}$ and anesthetized with pentobarbital sodium ( $60 \mathrm{mg} / \mathrm{kg}$ body weight i.p.). The gastrocnemius muscle was rapidly dissected, frozen in liquid nitrogen and stored at $-80^{\circ} \mathrm{C}$ until the analyses were performed.

The GLUT4 protein expression was determined by Western blotting and the enzyme activities including citrate synthase (CS), malate dehydrogenase (MDH), $\beta$-hydroxyacylCoA dehydrogenase ( $\beta \mathrm{HAD}$ ), hexokinase (HK), and lactate dehydrogenase (LDH) were measured spectrophotometrically as described previously (Suwa et al. 2008).

To compare the findings among the three groups, a one-way analysis of variance (ANOVA) was used. Fisher's PLSD was conducted if the ANOVA indicated a significant difference. A value of $P<0.05$ was considered to be significant.

The body mass prior to the treatment was similar in all three groups $(\mathrm{AL} ; 27.5 \pm 0.5 \mathrm{~g}, \mathrm{PF} ; 27.9 \pm 0.6 \mathrm{~g}$, BDNF; 27.6 $\pm 0.2 \mathrm{~g}$ ). The changes in the body mass in the $\mathrm{PF}(0.0 \pm 0.7 \mathrm{~g})$ and $\mathrm{BDNF}(-0.3 \pm 0.4 \mathrm{~g})$ groups were significantly lower than $\mathrm{AL}$ group $(1.7 \pm 0.4 \mathrm{~g})$ (Fig. 1A, $P<0.05$ ). Total food intake in the $\mathrm{PF}$ $(49.7 \pm 2.1 \mathrm{~g})$ and BDNF $(49.7 \pm 2.1 \mathrm{~g})$ groups were significantly lower than in AL group (58.7 $\pm 1.9 \mathrm{~g}$ ) (Fig. $1 \mathrm{~B}, P<0.01)$. These results suggest that BDNF treatment inhibits the body mass increase because of reducing food intake.

The GLUT4 protein expression in the BDNF group was significantly higher by $+37 \%$ and $+35 \%$ than in the $\mathrm{AL}$ and $\mathrm{PF}$ groups, respectively (Fig. $2, P<0.05$ ). Oxidative (CS, MDH and $\beta \mathrm{HAD}$ ) and glycolytic (HK and
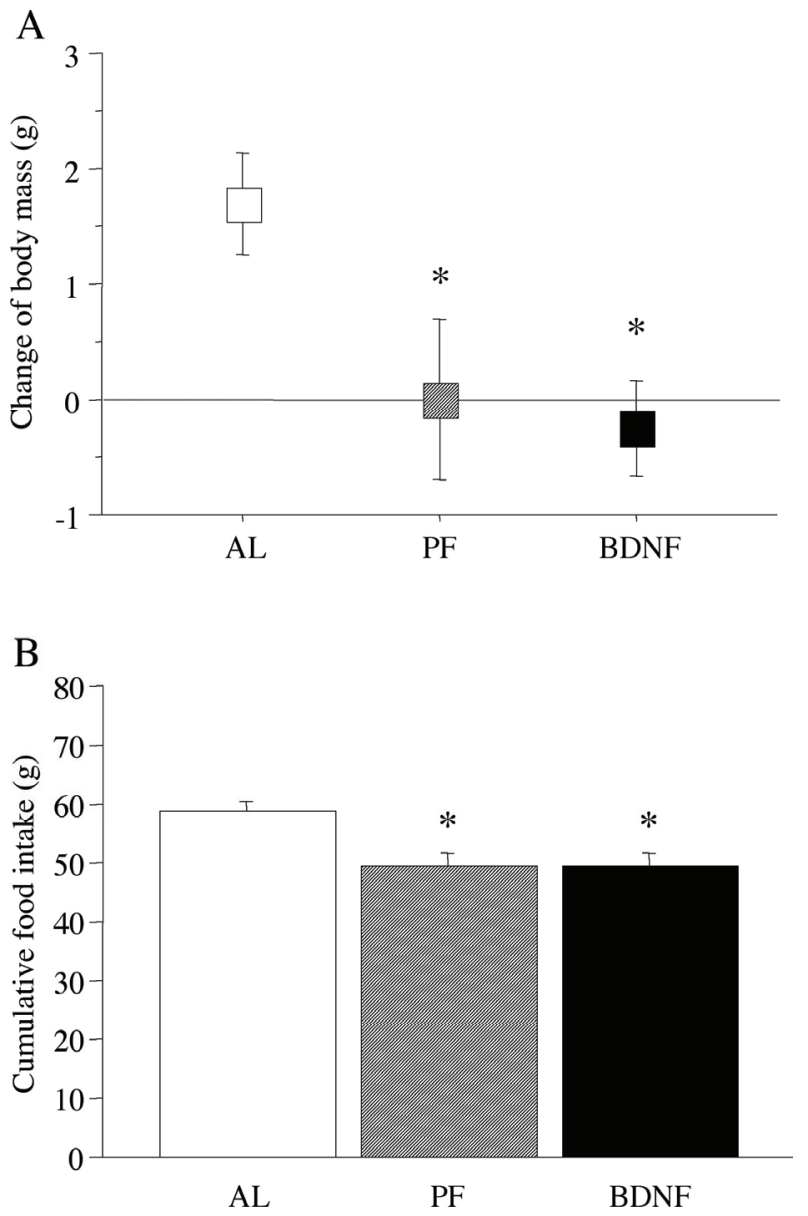

Fig. 1. A: Change of body mass during treatment. B: Cumulative food intake during the treatment. $\mathrm{N}=8$ per group. Data are expressed as the mean \pm S.E.M. *; P<0.05 vs. AL.

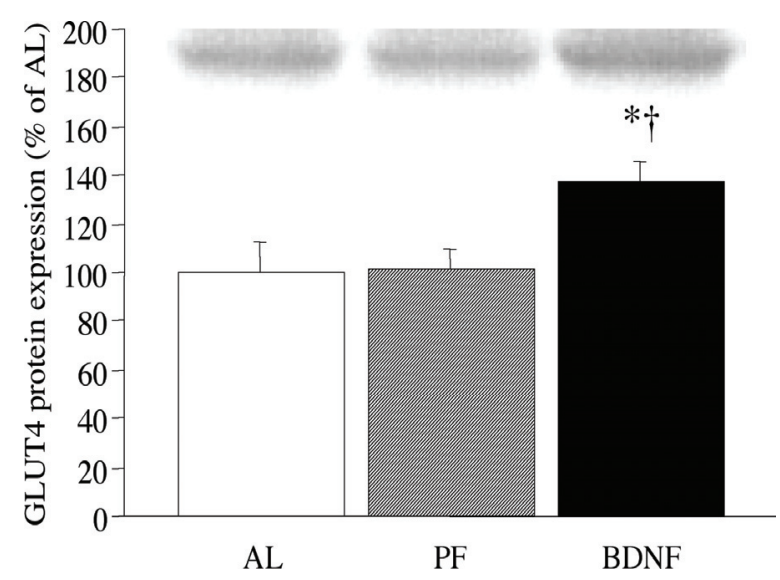

Fig. 2. GLUT4 protein expression of the gastrocnemius muscle in the 3 groups. $N=8$ muscles per group. Data are expressed as the mean \pm S.E.M. *; $P<0.05$ vs. AL. + ; $P<0.05$ vs. PF.

LDH) enzyme activities were measured, and no differences were observed among the groups in any enzymes (data not shown). 
The current study demonstrated that the subcutaneous BDNF injection to mice significantly decreased the food intake in agreement with the previous study (Nakagawa et al. 2003). In humans, the serum BDNF level may demonstrate a possible link with such eating disorders as bulimia nervosa and anorexia nervosa (Nakazato et al. 2003, Monteleone et al. 2004). Circulating BDNF may therefore play a role in suppressing food intake. BDNF expressed in ventromedial hypothalamus neurons has been shown to apparently suppress food consumption downstream of the melanocortin-4 receptor (Xu et al. 2003). Because BDNF can cross the blood-brain barrier (Pan et al. 1998), the subcutaneous injection of BDNF reduces the food intake possibly via hypothalamus neurons.

The most important finding in the current study is that the BDNF treatment increases the GLUT4 expression. GLUT4 plays an important role in skeletal muscle glucose uptake (Röckl et al. 2008). GLUT4 protein abundance is strongly associated with capacity of skeletal muscle glucose uptake (Doehner et al. 2010), suggesting that skeletal muscle GLUT4 abundance is a potential limiting factor of whole body and skeletal muscle glucose metabolism. The increasing GLUT4 protein expression in the current study is thus considered to improve the glucose metabolism.

Although it has been generally accepted that the neurotrophins act by either paracrine or autocrine mechanisms (Davies 1996), BDNF also exists in the blood (Radka et al. 1996). More than $90 \%$ of blood BDNF is stored in platelets, and platelets can release the
BDNF (Fujimura et al. 2002). Platelets are assumed to release $\mathrm{BDNF}$ at nerves or other tissues expressing BDNF receptor tyrosine kinase B (Fujimura et al. 2002). In addition, circulating BDNF level is associated with eating behavior (Monteleone et al. 2004), metabolic disorders (Chaldakov et al. 2003, 2004, Suwa et al. 2006), physical activity (Nofuji et al. 2008), depression (Brunoni et al. 2008), Alzheimer's disease (Laske et al. 2006), and cognitive function (Gunstad et al. 2008). We therefore presume that circulating BDNF might possess several of physiological functions including GLUT4 biogenesis and thereby mimic the endocrine mechanism.

Although this is only a preliminary study, the results presented herein raise the possibility that BDNF treatment may potentially contribute to the therapy of obesity and type II diabetes mellitus, while also helping to treat related cardiometabolic diseases. Further studies are necessary to identify the therapeutic effects of BDNF for such diseases and to clarify the mechanism underlying the effects of BDNF for GLUT4 expression and hypophagia.

\section{Conflict of Interest}

There is no conflict of interest.

\section{Acknowledgements}

This work was supported by a Grant-in-Aid for Scientific Research from the Ministry of Education, Culture, Sports, Science and Technology of Japan (No. 20650105) to Shuzo Kumagai.

\section{References}

BRUCE CR, ANDERSON MJ, CAREY AL, NEWMAN DG, BONEN A, KRIKETOS AD, COONEY GJ, HAWLEY JA: Muscle oxidative capacity is a better predictor of insulin sensitivity than lipid status. J Clin Endocrinol Metab 88: 5444-5451, 2003.

BRUNONI AR, LOPES M, FREGNI F: A systematic review and meta-analysis of clinical studies on major depression and BDNF levels: implications for the role of neuroplasticity in depression. Int J Neuropsychopharmacol 11: 1169-1180, 2008.

CHALDAKOV GN, FIORE M, HRISTOVA MG, ALOE L: Metabotrophic potential of neurotrophins: implication in obesity and related diseases? Med Sci Monit 9: HY19-21, 2003.

CHALDAKOV GN, FIORE M, STANKULOV IS, MANNI L, HRISTOVA MG, ANOTONELLI A, GHENEV PI, ALOE L: Neurotrophin presence in human coronary atherosclerosis and metabolic syndrome: a role for NGF and BDNF in cardiovascular disease? Prog Brain Res 146: 279-289, 2004.

CHALDAKOV GN, FIORE M, TONCHEV AB, DIMITROV D, PANCHEVA R, RANCIC G, ALOE L: Homo obesus: a metabotrophin-deficient species. Pharmacology and nutrition insight. Curr Pharm Des 13: 21762179, 2007.

DAVIES AM: Paracrine and autocrine actions of neurotrophic factors. Neurochem Res 21: 749-753, 1996. 
DOEHNER W, GATHERCOLE D, CICOIRA M, KRACK A, COATS AJ, CAMICI PG, ANKER SD: Reduced glucose transporter GLUT4 in skeletal muscle predicts insulin resistance in non-diabetic chronic heart failure patients independently of body composition. Int J Cardiol 138: 19-24, 2010.

FUJIMURA H, ALTAR CA, CHEN R, NAKAMURA T, NAKAHASHI T, KAMBAYASHI J, SUN B, TANDON NN: Brain-derived neurotrophic factor is stored in human platelets and released by agonist stimulation. Thromb Haemost 87: 728-734, 2002.

GUNSTAD J, BENTEZ A, SMITH J, GLICKMAN E, SPTZNAGEL MB, ALEXANDER T, JUVANCIC-HELTZEL J, MURRAY L: Serum brain-derived neurotrophic factor is associated with cognitive function in healthy older adults. J Geriatr Psychiatry Neurol 21: 166-170, 2008.

HE J, WATKINS S, KELLEY DE: Skeletal muscle lipid content and oxidative enzyme activity in relation to muscle fiber type in type 2 diabetes and obesity. Diabetes 50: 817-823, 2001.

KURODA A, YAMASAKI Y, MATSUHISA M, KUBOTA M, NAKAHARA I, NAKATANI Y, HOSHI A, GOROGAWA S, UMAYAHARA Y, ITAKURA Y, NAKAGAWA T, TAIJI M, KAJIMOTO Y, HORI M: Brain-derived neurotrophic factor ameliorates hepatic insulin resistance in Zucker fatty rats. Metabolism 52: 203-208, 2003.

LASKE C, STRANSKY E, LEYHE T, ESCHWEILER GW, WITTORF A, RICHARTZ E, BARTELS M, BUCHKREMER G, SCHOTT K: Stage-dependent BDNF serum concentrations in Alzheimer's disease. J Neural Transm 113: 1217-1224, 2006.

LEVINGER I, GOODMAN C, MATTHEWS V, HARE DL, JERUMS G, GARNHAM A, SELIG S: BDNF, metabolic risk factors, and resistance training in middle-aged individuals. Med Sci Sports Exerc 40: 535-541, 2008.

MONTELEONE P, TORTORELLA A, MARTIADIS V, SERRITELLA C, FUSCHINO A, MAJ M: Opposite changes in the serum brain-derived neurotrophic factor in anorexia nervosa and obesity. Psychosom Med 66: 744-748, 2004.

NAKAGAWA T, TSUCHIDA A, ITAKURA Y, NONOMURA T, ONO M, HIROTA F, INOUE T, NAKAYAMA C, TAIJI M, NOGUCHI H: Brain-derived neurotrophic factor regulates glucose metabolism by modulating energy balance in diabetic mice. Diabetes 49: 436-444, 2000.

NAKAGAWA T, OGAWA Y, EBIHARA K, YAMANAKA M, TSUCHIDA A, TAIJI M, NOGUCHI H, NAKAO K: Anti-obesity and anti-diabetic effects of brain-derived neurotrophic factor in rodent models of leptin resistance. Int J Obes Relat Metab Disord 27: 557-565, 2003.

NAKAZATO M, HASHIMOTO K, SHIMIZU E, KUMAKIRI C, KOIZUMI H, OKAMURA N, MITSUMORI M, KOMATSU N, IYO M: Decreased levels of serum brain-derived neurotrophic factor in female patients with eating disorders. Biol Psychiatry 54: 485-490, 2003.

NOFUJI Y, SUWA M, MORIYAMA Y, NAKANO H, ICHIMIYA A, NISHICHI R, SASAKI H, RADAK Z, KUMAGAI S: Decreased serum brain-derived neurotrophic factor in trained men. Neurosci Lett 437: 29-32, 2008.

PAN W, BANKS WA, FASOLD MB, BLUTH J, KASTIN A: Transport of brain-derived neurotrophic factor across the blood-brain barrier. Neuropharmacology 37: 1553-1561, 1998.

RADKA SF, HOLST PA, FRITSCHE M, ALTAR CA: Presence of brain-derived neurotrophic factor in brain and human and rat but not mouse serum detected by a sensitive and specific immunoassay. Brain Res 709: 122130, 1996.

RÖCKL KS, WITCZAK CA, GOODYEAR LJ: Signaling mechanisms in skeletal muscle: acute responses and chronic adaptations to exercise. IUBMB Life 60: 145-153, 2008.

SUWA M, KISHIMOTO H, NOFUJI Y, NAKANO H, SASAKI H, RADAK Z, KUMAGAI S: Serum brain-derived neurotrophic factor level is increased and associated with obesity in newly diagnosed female patients with type 2 diabetes mellitus. Metabolism 55: 852-857, 2006.

SUWA M, NAKANO H, RADAK Z, KUMAGAI S: Endurance exercise increases the SIRT1 and peroxisome proliferator-activated receptor $\gamma$ coactivator- $1 \alpha$ protein expressions in rat skeletal muscle. Metabolism 57: 986998, 2008. 
TSUCHIDA A, NONOMURA T, NAKAGAWA T, ITAKURA Y, ONO-KISHINO M, YAMANAKA M, SUGARU E, TAIJI M, NOGUCHI H: Brain-derived neurotrophic factor ameliorates lipid metabolism in diabetic mice. Diabetes Obes Metab 4: 262-269, 2002.

XU B, GOULDING EH, ZANG K, CEPOI D, CONE RD, JONES KR, TECOTT LH, REICHARDT LF: Brain-derived neurotrophic factor regulates energy balance downstream of melanocortin-4 receptor. Nat Neurosci 6: 736-742, 2003.

YAMANAKA M, TSUCHIDA A, NAKAGAWA T, NONOMURA T, ONO-KISHINO M, SUGARU E, NOGUCHI H, TAIJI M: Brain-derived neurotrophic factor enhances glucose utilization in peripheral tissues of diabetic mice. Diabetes Obes Metab 9: 59-64, 2007. 